\title{
Nauplius
}

The Journal of The

Brazilian Crustacean Society

This article is part of the tribute offered

by the Brazilian Crustacean Society

e-ISSN 2358-2936

www.scielo.br/nau www.crustacea.org.br

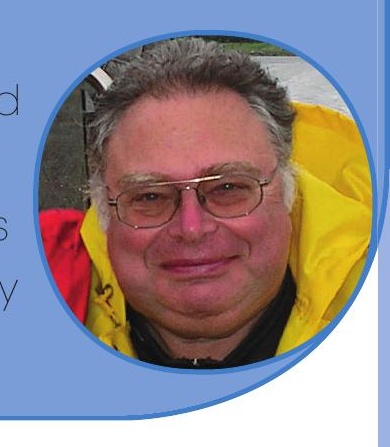

Original Article

\section{Taxonomy of the freshwater crab genus Neopseudothelphusa Pretzmann, 1965 (Decapoda: Brachyura: Pseudothelphusidae), with the description of a new genus}

\author{
Manuel Pedraza ${ }^{1}$ \\ ${ }^{1}$ Programa de Pós-Graduação em Sistemática, Taxonomia Animal e Biodiversidade, \\ Museu de Zoologia, Universidade de São Paulo. Av. Nazaré, 481, Ipiranga. 04263-000 \\ São Paulo, São Paulo, Brazil. \\ ZOOBANK http://zoobank.org/urn:lsid:zoobank.org:pub:DF9DFB3B-2109-48CC- \\ 89B1-1166B237C63C
}

\begin{abstract}
The taxonomy of the genus Neopseudothelphusa Pretzmann, 1965 is revised based on the morphology of the male first gonopod. A new genus, Culterthelphusa, is here proposed to receive Neopseudothelphusa simoni (Rathbun, 1905), while the genus Neopseudothelphusa is restricted to its type species, Neopseudothelphusa fossor (Rathbun, 1898). Illustrations of the first gonopod of both genera are provided.
\end{abstract}

\section{KEY WORDS}

Culterthelphusa, first gonopod, Kingsleyini, Neotropical region, macroinvertebrate fauna.

CORRESPONDING AUTHOR

Manuel Pedraza

manupedrazam@gmail.com

SUBMITTED 24 October 2016

ACCEPTED 28 December 2016

PUBLISHED 27 Abril 2017

Guest Editor

Célio Magalhães

DOI 10.1590/2358-2936e2017009 


\section{INTRODUCTION}

In most pseudothelphusid crabs, the carapace morphology is quite uniform and distinction at generic and specific level is only possible using the morphological characteristics of the male first gonopod (Rodriguez, 1982; Rodríguez and Magalhães, 2005). Neopseudothelphusa was initially established by Pretzmann (1965) as a subgenus of Guinotia Pretzmann, 1965 , to accommodate eight species. Nevertheless, the diagnostic characters provided by Pretzmann were little restrictive and, therefore, unsatisfactory for ascertaining the identity of Neopseudothelphusa. Rodriguez (1982) raised Neopseudothelphusa to full genus status, and transferred six of its eight species to other genera of Kingsleyini Bott, 1970, restricting it to two species: Neopseudothelphusa fossor (Rathbun, 1898) - its type species - and Neopseudothelphusa simoni (Rathbun, 1905). Even restricted to two species, Rodriguez (1982) acknowledged the artificiality of Neopseudothelphusa and justified the grouping of $N$. fossor with N. simoni merely on the basis of the proximity of their distribution limits in the Central Cordillera of Venezuela.

In a recent phylogenetic study of the Kingsleyini based on morphological characters (Pedraza, 2015), which included 49 out of 59 species currently known in the tribe, N. simoni and N. fossor were observed to exhibit remarkable differences in the morphology of their first gonopod. Therefore, a new genus, Culterthelphusa, is proposed herein to accommodate N. simoni, since the particularities in the morphology of its first gonopod do not allow its allocation in any other genus of Kingsleyini. Neopseudothelphusa is thus restricted to its type species, $N$. fossor.

\section{Material and Methods}

The terminology of the first gonopod follows Smalley (1964) and Pedraza et al. (2016). Line drawings of the first gonopod were made based on drawings and photographs produced with a stereomicroscope equipped with a camera lucida and then edited in Adobe Illustrator CC 2015. The following abbreviations were used: G1, male first gonopod; MZUSP, Museu de Zoologia da Universidade de São Paulo, São Paulo, Brazil; USNM, National Museum of Natural History, Smithsonian Institution, Washington, DC, USA. Diagnostic characters are based exclusively on the morphology of the male first gonopod.

\section{TAXONOMY}

Family Pseudothelphusidae Ortmann, 1893

\section{Tribe Kingsleyini Bott, 1970}

\section{Genus Neopseudothelphusa Pretzmann, 1965}

Guinotia (Neopseudothelphusa) Pretzmann, 1965: 3. Eudaniela (Neopseudothelphusa) - Pretzmann, 1971: 16. - Pretzmann, 1972: 19.

Neopseudothelphusa - Rodriguez, 1982: 167. - Ng et al., 2008: 175 [list]. - Villalobos and Álvarez, 2008: 299 [list]. — De Grave et al., 2009: 41 [list].

Diagnosis. G1 with marginal process straight, flat; apex truncated, fused to crest of distal lobe of apical plate. Apical plate narrow, subtriangular; distal and proximal lobes well distinct, split by deep notch; distal lobe larger than proximal lobe. Strong subterminal bulge in lateral view, its margin uniformly rounded.

Type species. Neopseudothelphusa fossor (Rathbun, $1898)$, by original designation.

Included species. Neopseudothelphusa fossor.

Distribution. Venezuela: Aragua, Distrito Capital, Miranda, Vargas.

Remarks. Neopseudothelphusa fossor is unique among the Kingsleyini in having the G1 with a strong subterminal bulge in lateral view and with its margin uniformly rounded (Fig. $1 \mathrm{~A}-\mathrm{C}$ ), and the marginal process of first gonopod fused to the crest of the distal lobe of the apical plate (Fig. 1B). The morphology of the G1 of $N$. fossor most resemble those of Kingsleya attenboroughi Pinheiro \& Santana, 2016, Kingsleya gustavoi Magalhães, 2005, Kingsleya hewashimi Magalhães \& Türkay, 2008, Kingsleya latifrons (Randall, 1840), Kingsleya siolii (Bott, 1967), and Kingsleya ytupora Magalhães, 1986, since the apical plate is narrow and subtriangular, with the distal and proximal lobes well distinct (Fig. 1A, C). Similarities and differences between $N$. fossor and Culterthelphusa simoni n. comb. are discussed in the remarks for the new genus. 

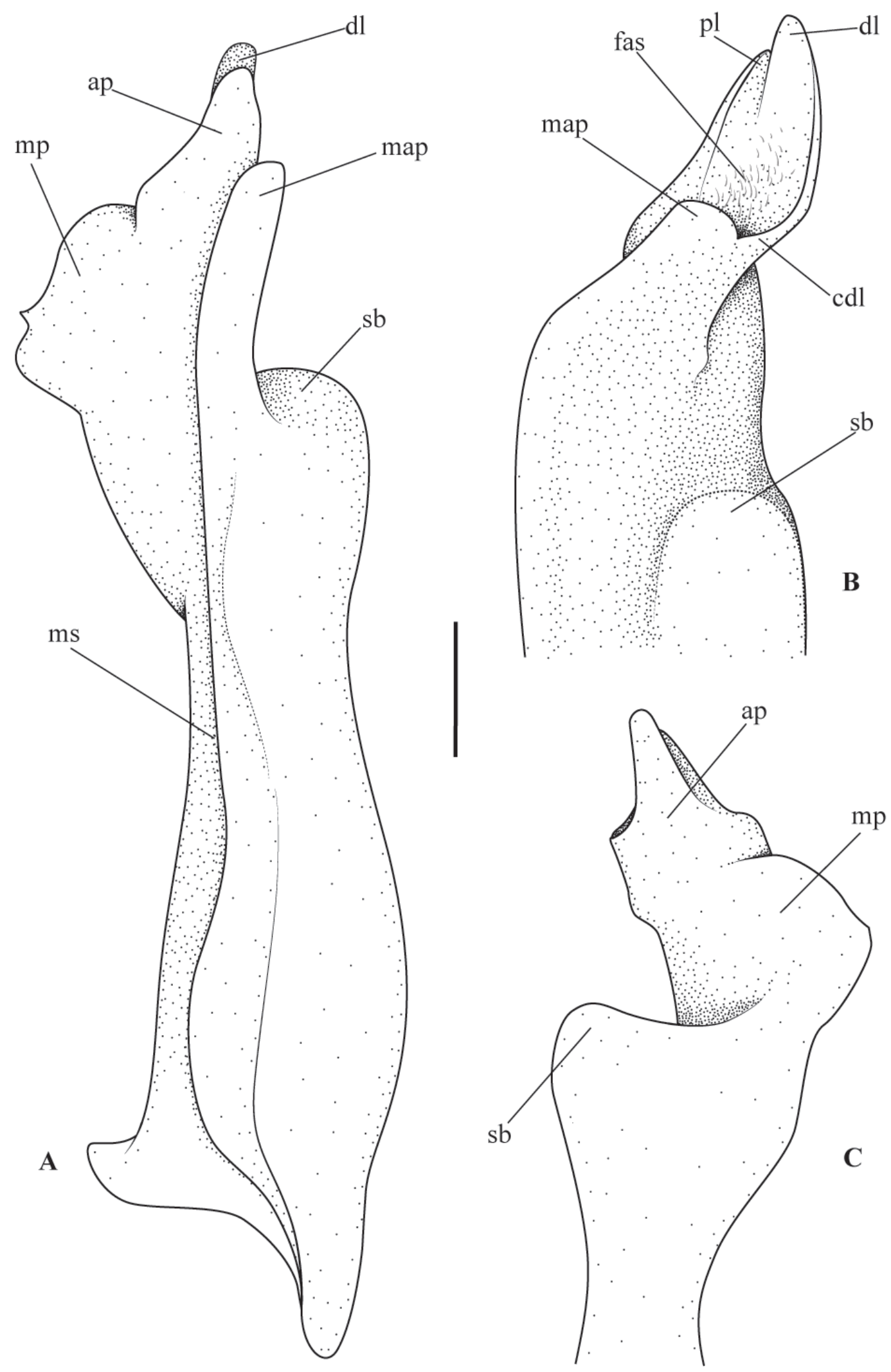

Figure 1. Neopseudothelphusa fossor (Rathbun, 1898) (USNM 23848), left first gonopod. A, abdominal view; B, lateral view; C, sternal view. Abbreviations: ap, apical plate; cdl, crest of distal lobe; dl, distal lobe; fas, field of apical spines; map, marginal process; $\mathrm{mp}$, mesial process; ms, marginal suture; pl, proximal lobe; sb, subapical bulge. Scale bar $=1 \mathrm{~mm}$. 
Neopseudothelphusa fossor (Rathbun, 1898)

(Fig. 1)

Pseudothelphusa fossor Rathbun, 1898: 520. Rathbun, 1904: 242. — Rathbun, 1905: 290, fig. 82. — Rathbun, 1906: 501. — Young, 1900: 208. —Coifmann, 1939: 108 [list]. — Rodríguez, 1966: 115, fig. 3.

Guinotia (Neopseudothelphusa) fossor - Pretzmann, 1965: 3 .

Eudaniela (Neopseudothelphusa) fossor fossor Pretzmann, 1971: 16. — Pretzmann, 1972: 21.

Eudaniela (Neopseudothelphusa) fossor aulae Pretzmann, 1972: 22.

Kingsleya fossor fossor - Bott, 1970: 356, figs. 9, 10. Kingsleya fossor aulae — Bott, 1970: 360, figs. 11, 12. Neopseudothelphusa fossor — Rodríguez, 1981: 49 [list]. - Rodriguez, 1982: 168, fig. $117-\mathrm{Ng}$ et al., 2008: 175 [list] — Villalobos and Álvarez, 2008: 299 [list].

Material examined. Venezuela, Vargas, La Guaira, 2.vii.1990, Lion \& Robinson leg., M. Campos det., 3 males, 2 females (USNM 23848).

Type locality. Venezuela, Distrito Capital: La Guaira.

\section{Genus Culterthelphusa n. gen.}

Diagnosis. G1 with marginal process large; apex sharp, slightly curved laterally. Mesial process simple, straight, cultriform, about twice as large as the apical plate. Apical plate wide, subquadrate, apex slightly bent to sternal side; distal and proximal lobes totally fused to apical plate.

Type species. Culterthelphusa simoni (Rathbun, 1905), n. comb., by monotypy and present designation.

Distribution. Venezuela: Aragua, Distrito Capital, Guárico, Miranda.

Etymology. The name Culterthelphusa is formed by the combination of the Latin word "cultratus", meaning knife, in reference to the shape of the mesial process of the first gonopod, which is unique in the tribe, with the suffix "thelphusa" for freshwater crab. The gender is feminine.
Remarks. Culterthelphusa n. gen. is established to accommodate C. simoni n. comb., formerly included in Neopseudothelphusa. Likewise, Culterthelphusa n. gen. is assigned to the tribe Kingsleyini as it shows the following diagnostic characters of the tribe: G1 with an apical plate projected beyond the opening of the spermatic channel; and G1 with basis widened along the sterno-abdominal axis. Culterthelphusa simoni n. comb. is unique in Kingsleyini in having the G1 with a simple mesial process, about three times longer than wide, cultriform in shape (Fig. 2A, C), and having the marginal process large, subtriangular and prolonged beyond the opening of spermatic channel (Fig. 2A, B).

\section{Culterthelphusa simoni (Rathbun, 1905) n. comb.} (Fig. 2)

Pseudothelphusa simoni Rathbun, 1905: 291. Rathbun, 1906: 501. — Coifmann, 1939: 109 [list]. - Weibezahn, 1952: 68. — Rodríguez, 1966: 118, fig 4.

Pseudothelphusa chacei Crane, 1949: 26, fig. 3. Weibezahn, 1952: 70.

Guinotia (Neopseudothelphusa) simoni simoni Pretzmann, 1965: 3.

Guinotia (Neopseudothelphusa) simoni chacei Pretzmann, 1965: 3.

Potamocarcinus (Kingsleya) venezuelensis simoni - Bott, 1967: 302, fig. 2.

Potamocarcinus (Kingsleya) venezuelensis venezuelensis — Bott, 1967: 302, fig. 1.

Eudaniela(Microthelphusa) simoni simoni - Pretzmann, 1971: 17. — Pretzmann, 1972: 23.

Eudaniela (Microthelphusa) simoni chacei - Pretzmann, 1971: 17. — Pretzmann, 1972: 24.

Neopseudothelphusa simoni - Rodríguez, 1981: 49 [list]. — Rodriguez, 1982: 167, fig 116. — Magalhães, 1987: 55, figs. 1, 2. — Ng et al., 2008: 175 [list].

Material examined. Venezuela, Aragua, Rancho Grande, 1100 m., 15.iii.1945, J. Crane leg., 1 male (USNM 87067). - Miranda, Parque Nacional Guatopo, 750 m., C. Brandão leg., C. Magalhães det., 1 male (MZUSP 6388); Turgua, 1100 m, 14.viii.1948, M. Campos det., 1 male, 1 female (USNM 89643); Turgua, 1099 m., 11.ix.1948, F. Martins leg., M. 


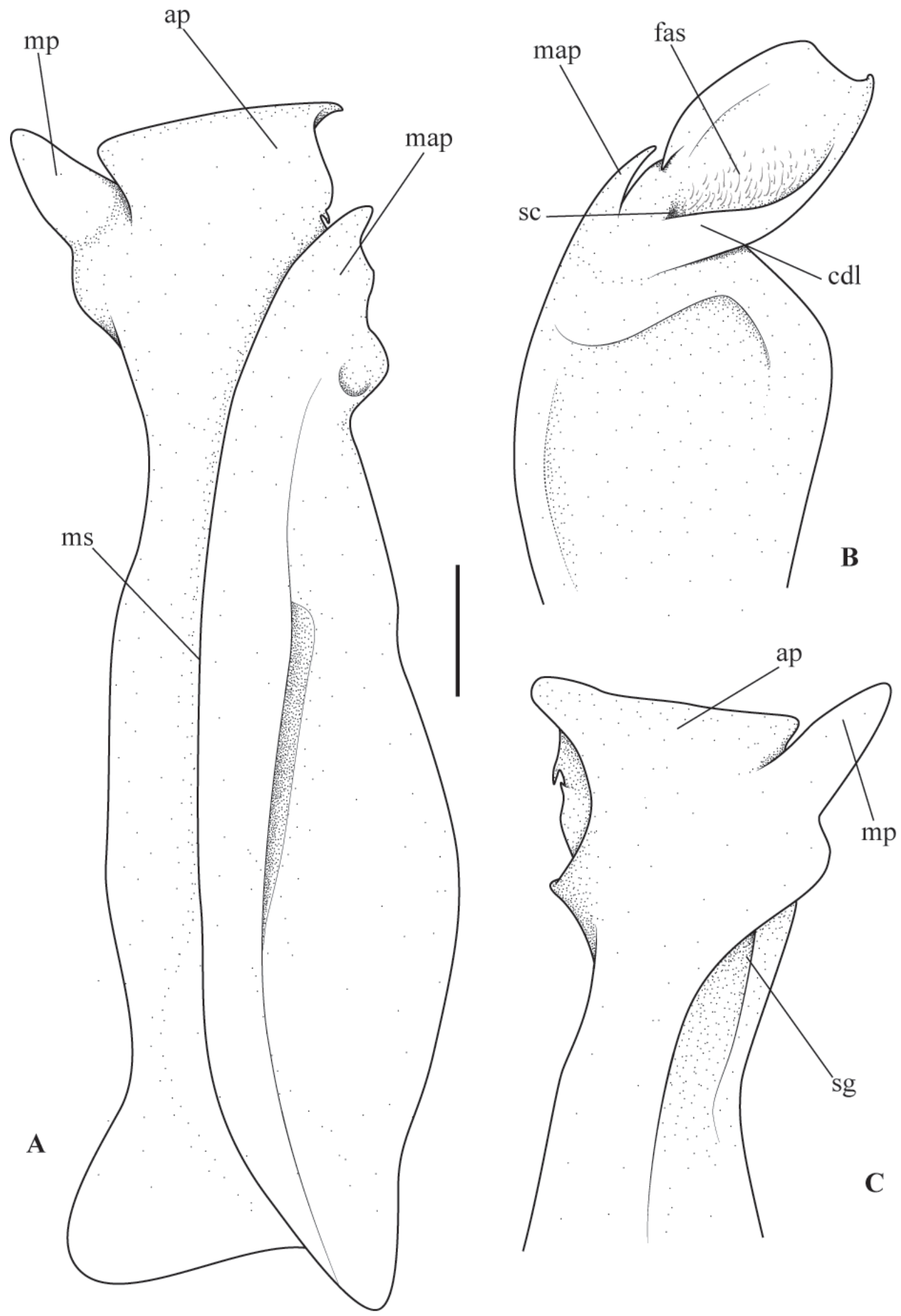

Figure 2. Culterthelphusa simoni (Rathbun, 1905) n. comb. (MZUSP 6388), left first gonopod. A, abdominal view; B, lateral view; C, sternal view. Abbreviations: ap, apical plate; cdl, crest of distal lobe; fas, field of apical spines; map, marginal process; mp, mesial process; ms, marginal suture; sc, opening of spermatic channel; sg, subapical groove. Scale bar $=1 \mathrm{~mm}$. 
Campos det., 2 males (USNM 90591). Turgua, 1100 m, 11.ix.1949, F. Martins leg., M. Campos det., 2 males (USNM 90602).

\section{Type locality. Venezuela, Aragua: Colonia Tovar.}

Remarks. Culterthelphusa simoni n. comb. differs from Neopseudothelphusa fossor in the following characters of the G1: (i) the marginal process is slightly curved to the lateral side, the apex is sharp, prolonged above the opening of spermatic channel in C. simoni n. comb. (Fig. 2A) [marginal process straight, apex truncated and prolonged at the same level of the opening of spermatic channel in N. fossor (Fig. 1A)]; (ii) the apex of the marginal process is well distinct from the crest of the distal lobe of the apical plate in C. simoni n. comb. (Fig. 2B) [apex of marginal process fused to the crest of the distal lobe of the apical plate in N. fossor (Fig. 1B) ]; (iii) the apical plate is large, wide, and subquadrate in C. simoni n. comb. (Fig. 2 A, B) [apical plate narrow and subtriangular in N. fossor (Fig. $1 \mathrm{~A}, \mathrm{~B})]$; (iv) the distal and proximal lobes of the apical plate are indistinct in C. simoni n. comb. (Fig. 2B) [distal and proximal lobes of the apical plate well distinct, split by a deep notch in N. fossor (Fig. 1A-C)] ; (v) there is a deep subterminal groove in sternal view, preceding the mesial process in C. simoni n. comb. (Fig. 2C) [sternal surface smooth, subterminal groove preceding the mesial process absent in N. fossor (Fig. 1C)]; (vi) the lateral surface is flat in the subterminal region, devoid of any subterminal bulge in C. simoni n. comb. (Fig. 2A-C) [strong subterminal bulge as seen in lateral view in N. fossor (Fig. 1A-C) ]; (vii) the mesial process is about twice as large as the apical plate, and is cultriformin C. simoni n. comb. (Fig. 2A, B) [mesial process almost the same size of the apical plate, subquadrate, in N. fossor (Fig. 1A, B)].

The morphology of the $\mathrm{G} 1$ of Culterthelphusa simoni n. comb. closely resembles that of Prionothelphusa eliasi Rodriguez, 1980 and Microthelphusa racenisi (Rodríguez, 1966) since in these three species the apical plate is wide, subquadrate, and the distal and proximal lobes are complete fused.

\section{ACKNOWLEDGMENTS}

I wish to thank Célio Magalhães and Marcos Tavares who encouraged and supported this study. I also thank Rafael Lemaitre (USNM) for a predoctoral fellowship and for providing working space and access to the Smithsonian collections, Karen Reed for helping with the collections, and the anonymous referees for their valuable suggestions and corrections. FAPESP (Fundação de Amparo à Pesquisa do Estado de São Paulo) provided financial support by way of the doctoral fellowship (2012/01334-7) conducted at the Museu de Zoologia, Universidade de São Paulo.

\section{References}

Bott, R. 1967. Flusskrabben aus Brasilien und benachbarter Gebiete. Potamocarcinus (Kingsleya) Ortmann 1897 (Crustacea, Decapoda). Senckenbergiana biologica, 48: 301312.

Bott, R. 1970. Betrachtungen über die Entwicklungsgeschichte und Verbreitung der Süsswasser-Krabben nach der Sammlung des Naturhistorischen Museums in Genf/Schweiz. Revue Suisse de Zoologie, 77: 237-344.

Coifmann, I. 1939. Potamonidi della Guiana Inglese raccolti dal Prof. Nello Beccari. Archivio Zoologico Italiano, 27: 93-116.

Crane, J. 1949. Fresh-water crabs of the genus Pseudothelphusa from Rancho Grande, Venezuela. Zoologica, 34: 25-30.

De Grave, S.; Pentcheff, N.D.; Ahyong, S.T.; Chan, T.; Crandall, K.A.; Dworschak, P. C.; Felder, D.L.; Feldmann, R.M.; Fransen, C.H.J.M.; Goulding, L.Y.D.; Lemaitre, R.; Low, M.E.Y.; Martin, J.W.; Ng, P.K.L.; Schweitzer, C.E.; Tan, S. H.; Tshudy, D. and Wetzer, R. 2009. A classification of living and fossil genera of decapod crustaceans. Raffles Bulletin of Zoology, Suppl. 21: 1-109.

Magalhães, C. 1986. Revisão taxonômica dos caranguejos de água doce brasileiros da família Pseudothelphusidae (Crustacea, Decapoda). Amazoniana, 9: 609-636.

Magalhães, C. 1987. Notes on some Pseudothelphusidae crabs from Venezuela, Ecuador and Mexico found in the collection of the Museu de Zoologia da Universidade de São Paulo, Brazil. Revista brasileira de Zoologia, 4: 55-58.

Magalhães, C. 2005. A new species of freshwater crab (Crustacea: Decapoda: Pseudothelphusidae) from the southeastern Amazon Basin. Nauplius, 12: 99-107. (2004).

Magalhães, C. and Türkay, M. 2008. A new species of Kingsleya from the Yanomami Indians area in the upper Rio Orinoco, Venezuela (Crustacea, Decapoda, Brachyura, Pseudothelphusidae). Senckenbergiana biologica, 88: 231-237. 
Ng, P.; Guinot, D. and Davie, P. 2008. Systema Brachyurorum: Part I. An annotated checklist of extant Brachyuran Crabs of the world. Raffles Bulletin of Zoology, Suppl. 17: 1-286.

Ortmann, A. 1893. Die Decapoden-Krebse des Strasbourg Museums, mit besonderer Berücksichtingung der von Herrn Dr. Döderlein bei Japan und bei den Liu-Kiu-Inseln gesammelten und zur Zeit im Strassburger Museum aufbewahrten Formen. VII. Theil. Abtheilung: Brachyura (Brachyura genuina Boas) 11. Unterabtheilung: Cancroidea, 2. Section: Cancrinea, 1. Gruppe: Cyclometopa. Zoologische Jahrbücher. Abtheilung für Systematik, Geographie und Biologie der Thiere, 7: 411-495.

Pedraza, M. 2015. Morfologia, taxonomia e análise cladística da tribo Kingsleyini (Crustacea: Decapoda: Pseudothelphusidae). Museu de Zoologia. Universidade de São Paulo, São Paulo, Brazil. Doctoral Thesis. 279p. [Unpublished]. Available at http://www.teses.usp.br/teses/disponiveis/38/38131/tde16032016-122758/en.php

Pedraza, M.; Magalhães, C. and Tavares M. 2016. A new genus of freshwater crab of the tribe Kingsleyini Bott, 1970 (Crustacea: Decapoda: Brachyura: Pseudothelphusidae) with description of a new species from Mato Grosso, Brazil. Zootaxa, 4173: 94-100.

Pinheiro, A.P. and Santana, W. 2016. A new and endangered species of Kingsleya Ortmann, 1897 (Crustacea: Decapoda: Brachyura: Pseudothelphusidae) from Ceará, northeastern Brazil. Zootaxa, 4171: 365-372.

Pretzmann, G. 1965. Vorläufiger Bericht über die Familie Pseudothelphusidae. Anzeiger der Mathematisch Naturwissenschaftliche der Österreichischen Akademie der Wissenschaften, 1: 1-11.

Pretzmann, G. 1971. Fortschritte in der Klassifizierung der Pseudothelphusidae. Anzeiger der Mathematisch Naturwissenschaftliche der Österreichischen Akademie der Wissenschaften, 179: 15-24.

Pretzmann, G. 1972. Die Pseudothelphusidae (Crustacea Brachyura). Zoologica, 120: 1-182.

Randall, J.W. 1840. Catalogue of the Crustacea brought by Thomas Nuttall and J.K. Towsend, from the West Coast of North America and the Sandwich Islands, with Descriptions of such Species as are apparently new, among which are included several Species of different Localities, previously existing in the Collection of the Academy. Journal of the Academy of Natural Science of Philadelphia, 8: 106-147 (1839).

Rathbun, M.J. 1898. A contribution to a knowledge of the freshwater crabs of America-The Pseudothelphusinae. Proceedings of the United States National Museum, 21: 507-537.
Rathbun, M.J. 1904. Les crabes d'eau douce (Potamonidae). Nouvelles Archives du Muséum d'Histoire naturelle, Paris, 6: 225-312.

Rathbun, M.J. 1905. Les crabes d'eau douce (Potamonidae). Nouvelles Archives du Muséum d'Histoire naturelle, Paris, 7: 159-321.

Rathbun, M.J. 1906. Catalogue des Potamonidés des collections du Muséum d'histoire naturelle de Paris, d'après les révisions et déterminations de Mlle. Mary Rathbun. Seconde et dernière partie. Bulletin du Muséum d'histoire naturelle, Paris, 12: 500504.

Rodríguez, G. 1966. The freshwater crabs of the genus Pseudothelphusa from northern Venezuela and Trinidad (Brachyura, Potamonidae). Zoologische Mededelingen, 41: 111-142.

Rodriguez, G. 1980. Descriptions préliminaires de quelques espèces et genres nouveaux de crabes d'eaux douce de l'Amérique Tropicale. Bulletin du Muséum national d'Histoire naturelle, Section A, Zoologie, Biologie et Ecologie Animales, Paris, 4e série, 2: 885-894.

Rodríguez, G. 1981. Decapoda. p. 1-51. In: S.H. Hurlbert; G. Rodríguez and D. Santos (eds), Aquatic Biota of Tropical South America, Part 1: Arthropoda. San Diego, San Diego State University.

Rodriguez, G. 1982. Les crabes d'eau douce d’Amérique. Famille des Pseudothelphusidae. Paris, ORSTOM, 223p. (Faune Tropicale, 22).

Rodríguez, G. and Magalhães, C. 2005. Recent advances in the biology of the Neotropical freshwater crab family Pseudothelphusidae (Crustacea, Decapoda, Brachyura). Revista brasileira de Zoologia, 22: 354-365.

Smalley, A. 1964. A terminology for the gonopods of the American River crabs. Systematics Zoology, 13: 28-31.

Villalobos, J.S. and Álvarez, F. 2008. Los cangrejos de agua dulce de la familia Pseudothelphusidae (Decapoda: Brachyura: Eubrachyura) de México, con un apéndice de las especies citadas para América hasta 2006. p. 239-300. In: F. Álvarez and G. Rodríguez-Almaraz (eds), Crustáceos de México: Estado actual de su conocimiento. Monterrey, Universidad Autonoma de Nuevo León.

Weibezahn, F.H. 1952. Contribución al estudio de los cangrejos dulceaquicolas da la región Baruta El Hatillo. Memoria de la Fundación La Salle de Ciéncias Naturales, 12: 67-70.

Young, C.G. 1900. The Stalk-Eye Crustacea of British Guiana, West Indies, and Bermuda. London, John M. Watkins Ed., 514p. 